\title{
Position Controller Design and Implementation of Ball and Beam System with SMC and PD Control Methods
}

\author{
Tayfun Abut* \\ Mus Alparslan University, Mus, 49100, Turkey
}

Received: October 04, 2020. Revised: November 09, 2020. Accepted: November 16, 2020.

() 2020 The Author. Published by Lviv Polytechnic National University.

\begin{abstract}
Today, several methods are proposed and tested for controlling many nonlinear and unstable systems. This study employed the sliding mode control (SMC) and proportional-derivative (PD), which are used to control the position and modeling of ball and beam system that is a fundamental system used to test the control methods. Such systems are nonlinear and unstable due to their nature. Therefore, these systems are affected by external disturbances and this leads to a decrease in the control quality. The study tested the system by utilizing the classical PD and SMC methods, and the results were assessed by employing the Integral-Square-Error (ISE) performance criterion. The system results were provided as graphics and tables. Besides, the results were compared and analyzed.
\end{abstract}

Keywords: ball and beam; modeling; sliding mode control; proportional-derivative control; integral-square-error.

\section{Introduction}

Ball and beam systems are difficult to control as they have an incomplete drive and non-linear structure. It is also one of the systems in which control methods are tested and compared. These systems are nonlinear and unstable. The fundamental objective in controlling such systems is to automatically control the beam angle to attain the needful position of the ball on the beam by carrying out a suitable torque to the joint. These systems have two degrees of freedom. The first one is the ball rolling up and down on the beam, and the other is the beam rotating along its central axis. This system has been studied many times, and diverse controllers have been recommended to control this poorly operated mechanism. Hauser et al. analyzed the nonlinear control via approximate input-output linearization: the case of ball and beam [1]. Teel recommended a hemispherical compensating feedback control that requires merely the measurement of the ball position and beams angle and does not require precise information about the ball mass or beam inertia for the simplified "ball and beam" [2]. Huang and Lin studied the robust nonlinear control of a ball and beam system. The method was supported by simulation results [3].

Yi et al. put forward a new fuzzy controller for stabilization control of a ball and beam system relying on a fuzzy inference model dynamically coupled to SIRMs (Single-input-rule-modules) [4]. An incremental sliding control method has been proposed and the application has been implemented [5]. Andreev et al. studied the matching control law of a similar system [6]. Yu and Ortiz recommended a complete model of a nonlinear ball and beam system and stability analysis of PD control. This experimentally suggested method was employed and its results were discussed [7]. Almutairi and Zribi proposed the SMC of the system. The proposed controller was supported by simulation and experimental studies [8]. Chang et al. Fuzzy suggested the fuzzy sliding-mode control by utilizing fuzzy ant colony optimization for a ball and beam system [9]. Chang et al. proposed a T-S fuzzy-model-based adaptive dynamic surface control for a ball and beam system. They conducted T-S fuzzy modeling-based simulation and experimental studies [10]. De La Torre et al. worked on a study

\footnotetext{
${ }^{*}$ Corresponding author. Email address: tayfunabut@gmail.com
}

This paper should be cited as: T. Abut. Position controller design and implementation of ball and beam system with SMC and PD control methods. Energy Engineering and Control Systems, 2020, Vol. 6, No. 2, pp. 120 - 126. https://doi.org/10.23939/jeecs2020.02.120 
aiming to improve a virtual and remote laboratory for the system by using Moodle. They performed applications using various methods [11]. Peraza et al. put forward a method referred to as the parameter adaptation in an FLC based harmony search algorithm (HS) for the optimization of ball and beam controller. Type 1 and type 2 fuzzy logic methods were analyzed utilizing some error performance criteria [12]. Mehedi et al. designed and employed a fractional degree controller on a two degree of freedom the ball and beam system. They presented a suitable assessment and comparison among integer and fractional order controllers in a numerical and experimental environment [13]. Du et al. designed a distortion prevention and control method employing an improved equivalent input distortion approach. They offered an equivalent input distortion (EID) approach developed to handle exogenous disturbances and system nonlinearities [14]. A robust observerbased adaptive fuzzy backstepping method for a similar system by Rahbar and Kalat is proposed. They were made researches for the method in a simulation environment [15].

This study employed the Sliding Mode Control (SMC) and Proportional-Derivative (PD), which are used to control the position and modeling of the ball and stick system that is a fundamental system used to test the control methods. Such systems are nonlinear and unstable due to their nature. Therefore, these systems are affected by external disturbances and this paves the way for a decrease in supervision quality. The aim was to increase the control quality of the system by utilizing sliding mode control and PD methods. Besides, the results were assessed by employing the Integral-Square-Error (ISE) performance criterion. The system results were provided as graphics and tables. Besides, the results were compared and analyzed.

\section{Modeling of the system}

Various methods are used in modeling in the literature. One of them is the Lagrange-Euler method. The method is basically an energy-based method. The model employed for system control algorithms was obtained by utilizing the Lagrange-Euler method [16]. Figure 1 depicts the free body diagram of the ball and beam system.

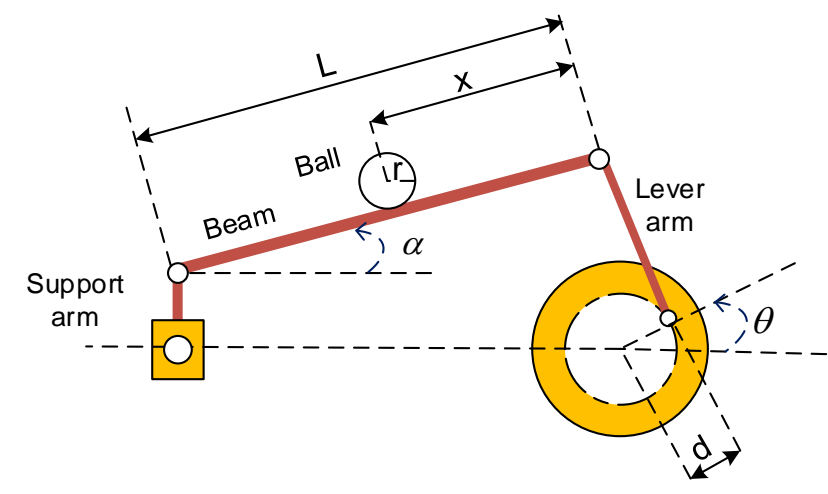

Fig.1. Free body diagram representation of the ball and beam system

In the system illustrated in Fig. 1, $\alpha$ and $x$ variable parameters indicate the beam inclination angle and the ball position, respectively. $\mathrm{L}$ is the beam length, $\mathrm{r}$ is the radius of the ball, $\mathrm{d}$ is the distance between the screw mounted point and the motor gear $\mathrm{d}$ and $\mathrm{m}$ is the mass of the ball. $\theta$ angle seems limited. Therefore, Equation 1 illustrates the mathematical relationship between the beam angle inclination $\alpha$ and $\theta$ (1):

$$
\alpha=\frac{d}{L} \theta,
$$

The model of the ball and beam system is provided in Equation 2:

$$
\left(\frac{J_{b}}{r^{2}}+m\right) \ddot{x}+m g \sin (\alpha)-m x \dot{\alpha}^{2}=0 .
$$

Equation 3 was obtained when equation 1 was inserted into equation 2. The parameters of the ball and beam system are shown in Table 1.

$$
\left(\frac{J_{b}}{r^{2}}+m\right) \ddot{x}+m g \sin (\theta)-m x \dot{\theta}^{2}=0 .
$$


Table 1. The system parameters.

\begin{tabular}{|c|c|c|}
\hline Symbol & Description & Value/Units \\
\hline \hline $\mathrm{m}_{\mathrm{b}}$ & Mass of ball & $0.064 \mathrm{~kg}$ \\
\hline $\mathrm{r}$ & The radius of the ball & $1.27 \mathrm{~cm}$ \\
\hline $\mathrm{L}$ & Beam length & $42.55 \mathrm{~cm}$ \\
\hline $\mathrm{d}$ & $\begin{array}{c}\text { Distance between screw-mounted } \\
\text { point and motor gear }\end{array}$ & $2.54 \mathrm{~cm}$ \\
\hline & Lever arm length & $12 \mathrm{~cm}$ \\
\hline & Support arm length & $16 \mathrm{~cm}$ \\
\hline
\end{tabular}

\section{Controller design for the ball and beam system}

The ball and beam systems are not stable, controllable, observable, and non-linear, the system must first be stabilized and then checked in designing the controller. The goal is to obtain a controller with minimal error to move the ball so that the real position of the ball reaches the desired position. What matters here is that $\alpha$ (beam angle) is controlled by the angle at the motor exit ( $\theta$ angle). Conventional PD controller and Sliding Mode Control (SMC) control methods were proposed for the system control.

\subsection{Proportional-derivative (PD) control}

While it is a former method employed in many implementations, the basic mathematical equation of a good performance PID control method is provided in equation 4 [17]. The closed-loop control type Ziegler-Nichols method was used to find the PID control coefficients [18]. Fig. 2 shows the schema of the PD control method designed for the system. $\theta_{d}$ reference entry angle signal, $\theta$ exit angle of the real system, $\mathrm{K}_{\mathrm{p}}$ proportional gain, $\mathrm{K}_{\mathrm{i}}$ integral gain, $\mathrm{K}_{\mathrm{d}}$ derivative gain, and $e=\theta_{d}-\theta$ an error signal are utilized to define them. In this study, the PD control method was utilized and the method formula is given in equation (5).

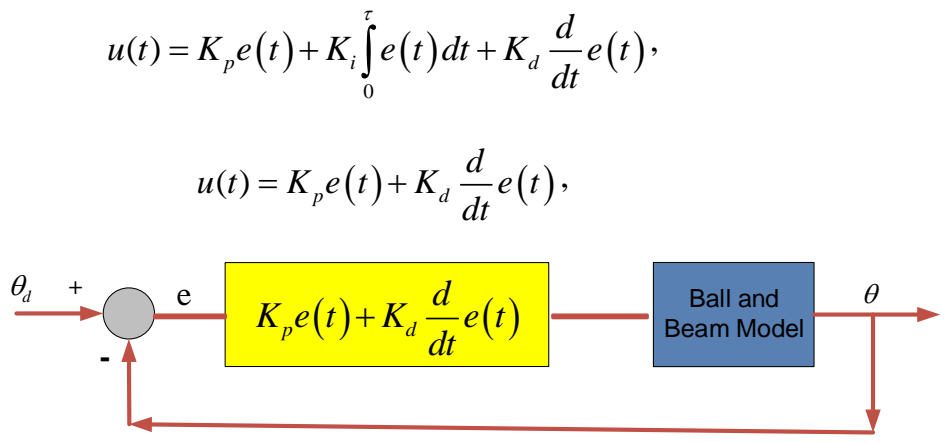

Fig.2. Block schema of the PD control method designed for the system

\subsection{Sliding mode control (SMC) method}

The second method used in the control of the system is the Sliding Mode Control (SMC) method, which has a high resistance to dynamic uncertainties. SMC is a special form of variable structured control. This method initially forces state variables to go on the sliding surface and then, they are kept on such surface and afterward, are shifted towards the origin [19]. Therefore, it is called the sliding surface as well as the switching surface. Thanks to its nature, it has a non-continuous control structure. This discrete control sign causes crackling. This harms the physical system elements. One of the ways to prevent this is to replace the discrete signum function that is in the sliding mode control sign with the saturation function, a continuous function thereof [20]-[21]. The position of the ball is the control variables of the robot. Fig. 3 shows the control structure of the sliding mode control (SMC). Equations containing the error and its derivative are provided in equations (6) and (7):

$$
\begin{gathered}
e(t)=\theta_{d}(t)-\theta(t), \\
\dot{e}=\dot{\theta}_{d}-\dot{\theta} .
\end{gathered}
$$




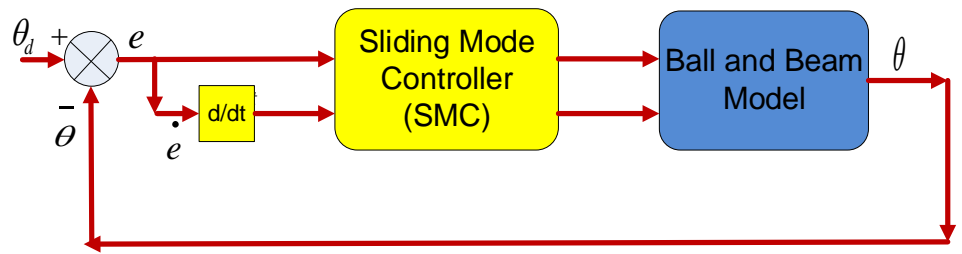

Fig.3. The control structure of the SMC method.

The reference input angle signal is referred to as $\theta_{d}$, exit angle of the actual system as $\theta$, and $e, \dot{e}$ are called error signals, respectively. The sliding surface is indicated by s. Equations 8 and 9 were obtained. $\lambda$ is a positively defined symmetric matrix and $\mathrm{k}$ is a constant parameter.

$$
\begin{gathered}
s=\dot{e}-\lambda e, \\
\dot{s}=\ddot{e}-\lambda \dot{e}, \\
u=-k * \operatorname{sign}(s), \\
\operatorname{sat}(s / \phi)=\left\{\begin{array}{cc}
\frac{s}{\phi} & \text { if }\left|\frac{s}{\phi}\right| \leq 1 \\
\operatorname{sign}(s / \phi) & \text { if }\left|\frac{s}{\phi}\right|>1
\end{array}\right\} .
\end{gathered}
$$

Signum is the sign function and s functions as switching. The Lyapunov criterion was employed for system stability. The sliding surface is illustrated in Fig.4. The saturation function was employed to solve the crackling problem. $\phi$ shows the thickness of the boundary layer.

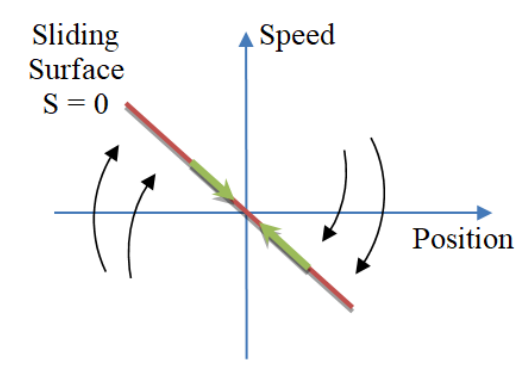

Fig.4. The concept of the sliding surface.

\section{Numerical simulation results}

This section includes the simulation activities obtained by employing motion equations of the ball and beam system. PD and Sliding Mode Control (SMC) algorithms were employed in controlling the system. The system's control variables are the ball position and engine angle. Square and step wave inputs were employed in the system. Thus, the best controller analysis was attempted by obtaining the results per Integral Square Error (ISE) criteria, which is the performance criterion of the applied control algorithms. The simulation time was identified as 50 seconds. Fig. 5 indicates the ball position and motor angle graphs obtained versus square and step input employing the PD method of the ball and beam system. As can be observed in Fig.5a, the peak overshoot occurs in the system per the graphic for the PD control method versus the square wave input. Besides, we observe that the system reached the settling time only in the 20th second. Similarly, the graph obtained for the step input indicates that the system overshoots the peak and reaches the settling time approximately in the 10th second, as can be observed in Fig.5b. 

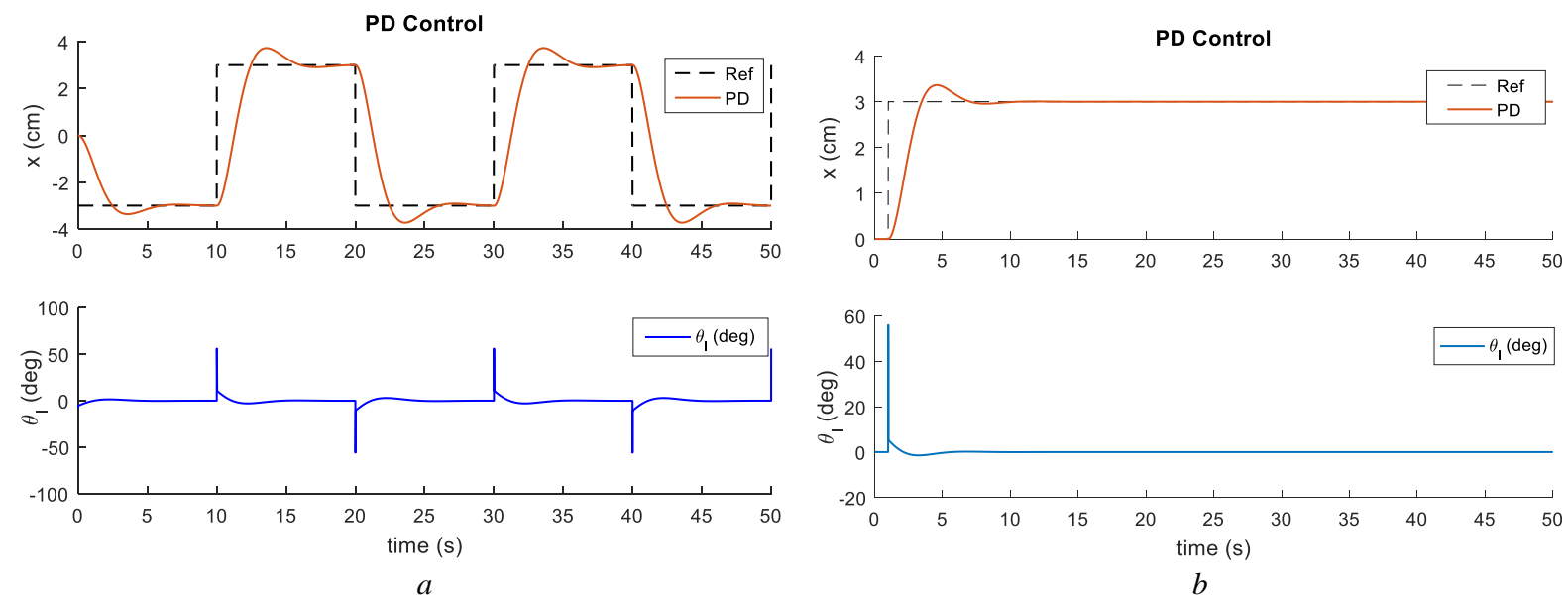

Fig.5. The square $(a)$ and the step $(b)$ input graphs by employing a PD control method for the ball position and motor angle.

Fig.6 indicates the ball position, motor angle graphs versus square, step input employing SMC of the system, and signum sign function. Fig.6a illustrates that the system does not overshoot the peak in the graph obtained by employing the SMC control method and the signum sign function versus the square wave input. Besides, it is observed that the system reached the settling time approximately in the 13th second. Similarly, the graph obtained for the step input indicates that the system does not overshoot the peak and reaches the settling time approximately in the 5th second, as can be observed in Fig. 6b. However, a crackling problem, which is a negative effect of the signum sign function, occurred as can be observed in the angle graphs from the system versus both inputs. This is considered as a negative situation for the system. To correct the negative situation in Fig. 6, the results were obtained by employing the saturation function instead of the signum sign function.
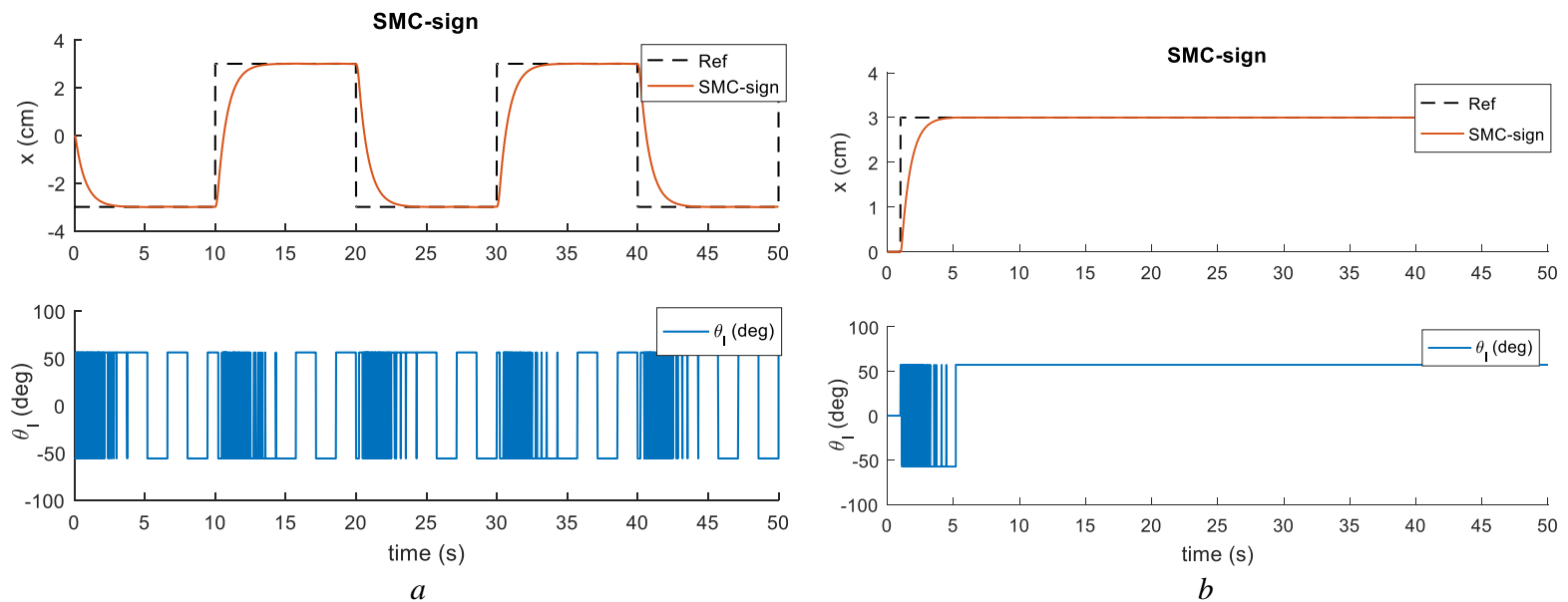

Fig.6. The square (a) and the step $(b)$ input graphs by employing the SMC control method and signum sign function for the ball position and motor angle.

Fig.7 illustrates the ball position and motor angle graphs versus square and step input by employing SMC of the system and saturation sign function. Fig.7a illustrates that the system does not overshoot the peak in the graph obtained by employing the SMC control method and the signum sign function versus the square wave input. Besides, it is observed that the system reached the settling time approximately in the 13th second. Similarly, the graph obtained for the step input indicates that the system does not overshoot the peak and reaches the settling time approximately in the 5th second, as can be observed in Fig. 6b. A crackling problem, which is a negative effect of the signum sign function, was solved with saturation function as can be observed in the angle graphs from the system versus both inputs. The performance index ISE is given in the following equation 


$$
I S E=\int_{0}^{\infty}\left(y_{d_{j}}-y_{j}\right)^{2} d t
$$

where $y_{d j}$ is the desired $j$ value; $y_{j}$ is the real $j$ value of the robot; $y$ is the position of the ball $(x) ; j=1,2,3,4 \ldots . \mathrm{N}$ '.
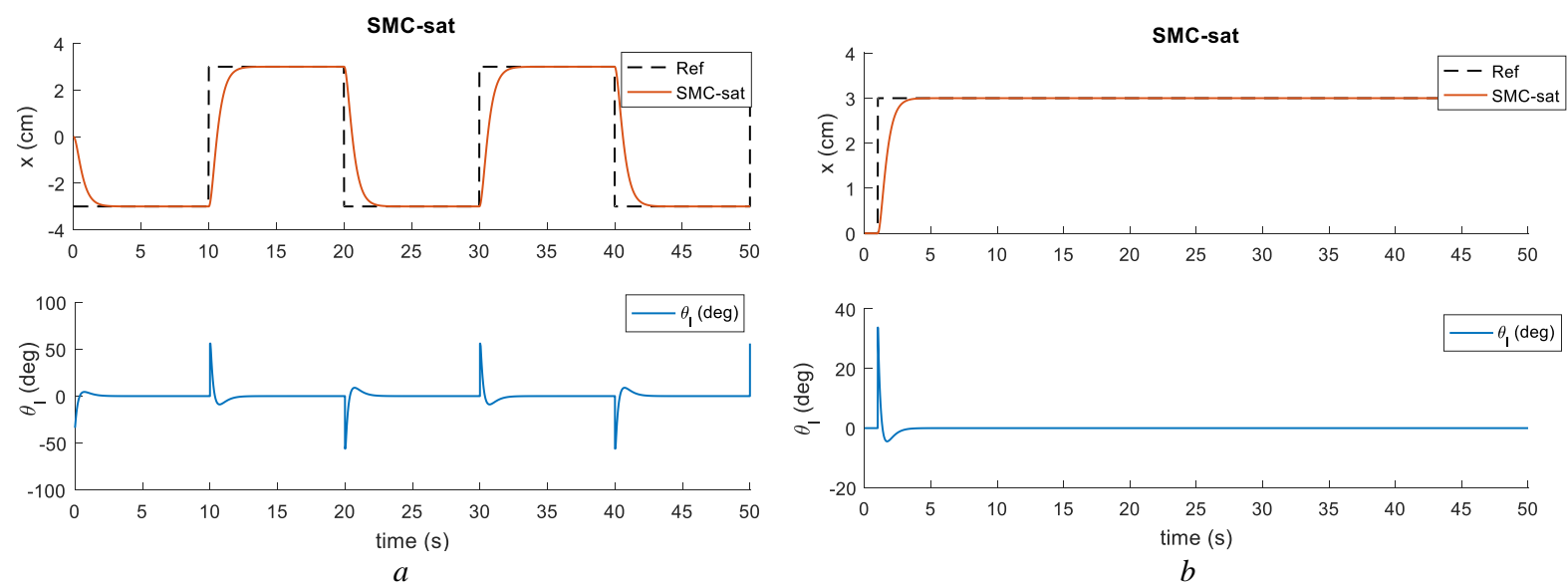

Fig.7. The square $(a)$ and the step $(b)$ input graphs by employing the SMC control method and saturation sign function for the ball position and motor angle.

Table 2 indicates the error results obtained by employing the performance criteria ISE of the PD and SMC control methods versus square and step inputs.

Table 2. The error results according to performance criteria.

\begin{tabular}{|c|c|c|}
\hline ISE & PD Control & SMC-sat \\
\hline \hline Square input & 0.0145 & 0.0029 \\
\hline Step input & 0.00185 & 0.00015 \\
\hline
\end{tabular}

For the ball position results provided in Table 2, the best error rate versus square entry was obtained by the SMC control method and the result was $0.0029 \mathrm{~cm}$. The value obtained by employing the PD control method is $0.0145 \mathrm{~cm}$. The best error rate versus the step input, which is another input provided in the table, was obtained by the SMC control method and the result is $0.00015 \mathrm{~cm}$. The value obtained by employing the PD control method is $0.00185 \mathrm{~cm}$. The results indicate that the best error rate is obtained by employing the SMC method versus step input. In general, the SMC method shows superior performance.

\section{Conclusion}

This study employed the Sliding Mode Control (SMC) and Proportional-Derivative (PD), which are used to control position. Modeling was carried out for the ball and beam system that is a fundamental system used to test the control methods. The system was controlled by applying conventional PD and Sliding Mode Control methods. Besides, the results were assessed by employing the Integral-Square-Error (ISE) performance criterion. The SMC method provided the best performance results for both peak overshoot and settling time. The best error rate versus the step input, which is another input provided in the table, was obtained by the SMC control method and the result was $0.00084 \mathrm{~cm}$. The value obtained by applying the PD control method was $0.0015 \mathrm{~cm}$. The results indicate that the best error rate was obtained by applying the SMC method versus step input. In general, the SMC method shows superior performance. Besides, the method can be developed by employing different optimization techniques and objective functions. The method can also be developed and applications can be made in a real-time laboratory environment in future studies.

\section{References}

[1] Hauser, J., Sastry, S., and Kokotovic, P. (1992). Nonlinear control via approximate input-output linearization: The ball and beam example. IEEE transactions on automatic control, 37(3), 392-398.

[2] Teel, A. R. (1993, June). Semi-global stabilization of the ball and beam 'using output' feedback. In 1993 American Control Conference (pp. 2577-2581). IEEE. 
[3] Huang, J., and Lin, C. F. (1995, June). Robust nonlinear control of the ball and beam system. In Proceedings of 1995 American Control Conference-ACC'95 (Vol. 1, pp. 306-310). IEEE.

[4] Yi, J., Yubazaki, N., and Hirota, K. (2001, July). Stabilization control of ball and beam systems. In Proceedings Joint 9th IFSA World Congress and 20th NAFIPS International Conference (Cat. No. 01TH8569) (Vol. 4, pp. 2229-2234). IEEE.

[5] Andreev, F., Auckly, D., Gosavi, S., Kapitanski, L., Kelkar, A., and White, W. (2002). Matching, linear systems, and the ball and beam. Automatica, 38(12), 2147-2152.

[6] Hirschorn, R. M. (2002). Incremental sliding mode control of the ball and beam. IEEE Transactions on Automatic Control, 47(10), 16961700 .

[7] Yu, W., and Ortiz, F. (2005, August). Stability analysis of PD regulation for ball and beam system. In Proceedings of 2005 IEEE Conference on Control Applications, 2005. CCA 2005. (pp. 517-522). IEEE.

[8] Almutairi, N. B., and Zribi, M. (2010). On the sliding mode control of a ball on a beam system. Nonlinear dynamics, 59(1-2), 221.

[9] Chang, Y. H., Chang, C. W., Tao, C. W., Lin, H. W., and Taur, J. S. (2012). Fuzzy sliding-mode control for ball and beam system with fuzzy ant colony optimization. Expert Systems with Applications, 39(3), 3624-3633.

[10] Chang, Y. H., Chan, W. S., and Chang, C. W. (2012). TS fuzzy-model-based adaptive dynamic surface control for ball and beam system. IEEE transactions on industrial electronics, 60(6), 2251-2263.

[11] De La Torre, L., Guinaldo, M., Heradio, R., and Dormido, S. (2015). The ball and beam system: A case study of virtual and remote lab enhancement with moodle. IEEE Transactions on Industrial Informatics, 11(4), 934-945.

[12] Peraza, C., Valdez, F., Castro, J. R., and Castillo, O. (2018). Fuzzy dynamic parameter adaptation in the harmony search algorithm for the optimization of the ball and beam controller. Advances in Operations Research, 2018.

[13] Mehedi, I. M., Al-Saggaf, U. M., Mansouri, R., and Bettayeb, M. (2019). Two degrees of freedom fractional controller design: Application to the ball and beam system. Measurement, 135, 13-22.

[14] Du, Y., Cao, W., She, J., Wu, M., Fang, M., and Kawata, S. (2019). Disturbance Rejection and Control System Design Using Improved Equivalent Input Disturbance Approach. IEEE Transactions on Industrial Electronics, 67(4), 3013-3023.

[15] Rahbar, F., and Kalat, A. A. (2020). An Observer-Based Robust Adaptive Fuzzy Back-Stepping Control of Ball and Beam System. Arabian Journal for Science and Engineering, 45(3), 1397-1409.

[16] Hazewinkel, Michiel, ed. (2001), "Lagrange equations (in mechanics)", Encyclopedia of Mathematics, Springer, ISBN 978-1-55.

[17] Abut, T.and Soyguder, S. (2018). Interface Design and Performance Analysis for a Haptic Robot. Muş Alparslan Üniversitesi Fen Bilimleri Dergisi, 6(2), 553-560.

[18] Ziegler, J. G., and Nichols, N. B. (1942). Optimum settings for automatic controllers. trans. ASME, 64(11).

[19] Utkin, V. I. (1993). Sliding mode control design principles and applications to electric drives. IEEE transactions on industrial electronics, 40(1), 23-36.

[20] Utkin, V., Guldner, J., and Shijun, M. (1999). Sliding mode control in electro-mechanical systems (Vol. 34). CRC press.

[21] Hüseyinoğlu, M., and Abut T. (2018). Dynamic Model and Control of 2-DOF Robotic Arm. European Journal of Technique, 8(2), 141-150.

\title{
Проектування та впровадження регулятора положення системи «куля-балка» методами ковзного режиму та ПД регулювання
}

\author{
Тайфун Абут \\ Університет Муш Алпарслан, Муш, 49100, Туреччина
}

\section{Анотація}

Станом на сьогодні запропоновано і перевірено декілька методів керування багатьма нелінійними та нестійкими системами. У цьому дослідженні використано ковзний режим керування та пропорційнодиференціальний (ПД) регулятор, які використовуються для керування положенням та моделювання системи «куля-балка», що є базовою системою для перевірки методів керування. Такі системи є нелінійними та нестійкими за своєю природою і на них впливають зовнішні збурення. У цій роботі досліджено систему із застосуванням класичного ПД регулятора та ковзного режиму керування. Результати були оцінені із застосування інтегральної квадратичної оцінки. Результати представлені у вигляді графіків та таблиць. Крім цього, виконано порівняння та аналіз результатів.

Ключові слова: куля-балка; моделювання; керування; ковзний режим керування; пропорційнодиференціальний; інтегральна квадратична оцінка. 